\title{
Innovation of Talents Training Mode of Communication Technology Major Based on College-Enterprise Cooperation
}

\author{
Luo Quanzhen ${ }^{1}$, Zhao $\mathbf{Q i}^{2}$, Zhang Jianchang ${ }^{3}$ \\ ${ }^{1}$ Department of Information Engineering, Gansu Vocational and Technical College of Communications, Lanzhou, China \\ ${ }^{2}$ Department of Management Engineering, Gansu Vocational and Technical College of Communications, Lanzhou, China \\ ${ }^{3}$ Operations Department, Beijing Huatec Information Technology Co. Ltd, Beijing, China
}

Email address:

bxbz@qq.com (Luo Quanzhen)

\section{To cite this article:}

Luo Quanzhen, Zhao Qi, Zhang Jianchang. Innovation of Talents Training Mode of Communication Technology Major Based on College-Enterprise Cooperation. American Journal of Engineering and Technology Management. Vol. 4, No. 1, 2019, pp. 1-4. doi: 10.11648/j.ajetm.20190401.11

Received: June 5, 2018; Accepted: December 11, 2018; Published: March 29, 2019

\begin{abstract}
By taking Gansu Vocational and Technical College of Communications as an example, the innovation of the talent cultivation mode of Communication Technology majors based on college-enterprise cooperation is explored. The extensive cooperation with communication equipment manufacturing enterprises is carried out, and the college-enterprise cooperation mode of "Relying on one enterprise, cooperation with ten and serving one hundren" is developed. The ZTE (Zhongxing Telecommunication Equipment Corporation) Telecom College and the ZTE ICT industry innovation base are established with the college-enterprise cooperation, and the teaching tem of the mixed teachers plus enterprise engineers plus enterprise certification instructors is built up. The research is carried out from the aspects of talent cultivation mode innovation, teachers' team construction, student management, dual certificates, employment and entrepreneurship, and the good results are achieved.
\end{abstract}

Keywords: College-Enterprise Cooperation, Teachers Construction, Vocational and Technical Education

\section{Introduction}

In order to meet the requirements of high quality technical talents for the development of social and economic development, the higher vocational colleges should be more close to the actual needs of the enterprise, and pay more attention to the training of the students' practical ability in the course of teaching. Deepening the college-enterprise cooperation is the inevitable trend of the reform and development of Vocational Education in China. It is an effective way to train excellent professionals. It is an inevitable choice to stimulate the vitality of vocational education and promote the reform of talent training effectively [1-2].

However, at present, some vocational colleges in China, especially in the northwestern region, have some problems in school-enterprise cooperation [3]. Our college is a provincial public higher vocational college. The college has good cooperation with ZTE Corporation and develops cooperative talents for communication major [4-5]. This paper attempts to expound and discuss the cooperation between college and enterprise in communication major, and hopes to provide reference for other higher vocational colleges.

\section{The Necessity of School-Enterprise Cooperation in Communication Major}

Communication major is a rapidly developing major. Many higher vocational colleges have set up communication technology specialty. In recent years, new technologies related to communications, such as 4G/5G, NB-IoT, SDN/NFV, cloud computing, big data, virtualization, emerge in endlessly. The construction and development of communication technology specialty in Higher Vocational Colleges urgently need to cooperate with enterprises in depth, so as to constantly update the training program and curriculum system to cultivate high-quality technical skills talents in accordance with the market demand [6]. 
Teachers in higher vocational colleges must constantly learn new knowledge and skills so as to keep up with the development of technology and improve their teaching level [7].

It is the inevitable trend and the best choice to carry out cooperation with communication equipment manufacturers in communication major. First of all, communications equipment production enterprises, such as HUAWEI and ZTE Corporation, have played a leading role in the industry development, market guidance and standard formulation. Secondly, these enterprises have a large number of downstream businesses, and they will be an important job market, which can fully satisfy the employment of vocational college graduates. Third, enterprises often carry out technical training to customers and agents. So they can provide good training conditions for teachers in vocational colleges [8]. Fourth, enterprises have obvious advantages in technology development and social services.

\section{Analysis of College-Enterprise Cooperation Mode of Communication Technology Major}

\subsection{Formed New College-Enterprise Cooperation Mode}

In the construction and development of communication technology major, Gansu Vocational and Technical College of Communications is closely linked with enterprises, and finally formed a college-enterprise cooperation mode of "Relying on one enterprise, cooperation with ten and serving one hundren."

"Relying on one enterprise", is relying on one leading enterprise -- ZTE Corporation. "Cooperation with ten", is to cooperate with ten or more representative enterprises in the region, such as Lanzhou Telecom and Lanzhou mobile. "serving one hundred", is ultimately serving hundreds of related enterprises.

\subsection{Set up ZTE Telecom College}

Gansu Vocational and Technical College of Communications and ZTE Corporation jointly established ZTE Telecom College. We will start the education of communication major, through the cooperation mechanism of "talent co education, process co management, results sharing and responsibility sharing".

ZTE Corporation gives the guidance of the enterprise management mode, and the college gives the guidance of school management mode. In terms of teaching, ZTE Telecom College follows the direction of the College. On this basis, the vocational management model is introduced to strengthen the training of students' quasi professional orientation, career orientation and job hunting ability.

\subsection{Building the ICT Industry Innovation Base}

Gansu Vocational and Technical College of Communications and ZTE Corporation jointly build ICT (Information and Communication Technology) industry innovation base. The College provides field and supporting facilities, and the company is responsible for the design, installation and commissioning of the base. Based on the commercial system of telecom operators and the whole process of end to end delivery in the communications industry, the base is highly suited to the development trend of the industry. It includes the training platform and the management system, such as solid network training base, enterprise information training base, mobile communication training base, communication engineering construction training platform, etc. The base has become the largest number of training equipment and simulation systems in Gansu Province. The base's total value is 10 million 320 thousand yuan. It was recognized as "ICT industry innovation base of the Ministry of Education \& ZTE" in July 2014.

The base has strengthened the professional construction, improved the conditions for running school, expanded the scale of school, and formed a strong radiation function, demonstration function and social service function. The perfect management system was established in the base. Students can study all day, and the utilization rate of equipment is very efficient. The base is also open to the society, providing technical training and social services. Through education resource sharing, the utilization efficiency of base resources can be maximized.

\subsection{Mixed Teaching Team of Teacher + Enterprise Engineer + Enterprise Certification Instructor}

Constructing a double qualified teaching team composed of college professional teachers, enterprise engineers and enterprise certification instructor. The college teachers undertake the teaching tasks of public courses, professional basic courses and professional elective courses. The enterprise engineers undertake the core courses and guide the graduation design work. Enterprise engineers can be recruited for record as college teachers, and the teachers can join the enterprise in line with the requirements of the enterprise.

After several years of continuous development, the connotation of communication technology major has been strengthened. A professional teaching team has been created. Which their age and knowledge structure are reasonable, their professional quality is excellent, the "three divisions"(teacher + enterprise engineer + enterprise certification instructor) structure is optimized. It has won the praise from students, parents and enterprises.

\subsection{College and ENTERPRISE Jointly Cultivate Talents}

From 2013 to now, under the conditions of good college-enterprise co-construction environment, advanced hardware conditions and superior mixed teaching team, the communication major has developed rapidly, and the quality of personnel training has been continuously improved. Students, parents and enterprises have consistently praised it. Table 1 is the number of students enrolled in the communication major. In 2017, this major was rated as a high quality major of college-level. 
Table 1. Number of students enrolled in communication Major.

\begin{tabular}{llllllll}
\hline Year & $\mathbf{2 0 1 2}$ & $\mathbf{2 0 1 3}$ & $\mathbf{2 0 1 4}$ & $\mathbf{2 0 1 5}$ & $\mathbf{2 0 1 6}$ & $\mathbf{2 0 1 7}$ & $\mathbf{2 0 1 8}$ \\
\hline Number of students enrolled in communication Major & 56 & 92 & 108 & 190 & 199 & 206 & 202 \\
\hline
\end{tabular}

\section{Reform of Communication Technology and Innovation of Talent Training Mode}

\subsection{Taking the Industry Competency Model as the Guidance, Innovating the Talent Training Mode}

In accordance with the teaching standards and human resource requirements, based on the competency model of communication and ICT industry, enterprises and college professionals jointly formulate training programs, teaching plans and curriculum standards for communication major. The talent training plan is updated every year to ensure the synchronization of market demand. The personnel training mode has the characteristics of integration of teaching, learning and doing based on project guidance and task driven. Enterprise training materials, technical standards and skills training methods were introduced into the professional teaching plan and curriculum system.

\subsection{Taking the Working Competency Model as the Guidance, Strengthen the Construction of Teachers}

In the process of the construction of the teachers' team, the college not only pay attention to whether teachers have obtained technical certificate, but also pay special attention to whether teachers' ability are improved. ZTE Corporation also requires teachers to play the role of corporate lecturers, enterprise project managers and enterprise technical directors, etc. Therefore, the transformation of teacher role from "double-teacher" to "three-teacher" has been realized.

ZTE Telecom College built a typical enterprise environment inside, which makes practice teaching no longer rely entirely on enterprises. The teaching of professional core courses is based on the whole process of the end to end delivery of communication engineering projects, and the modern apprenticeship mode is adopted with the teacher and apprenticeship, and the delivery process of the project is moved to the campus. The teaching process includes the students' professional management, the automated instruction of the engineers, the training on demand, the MIMPS (project and task driven) teaching method, the employment service system and so on. For the equipment production enterprises, engineering construction enterprises, maintenance companies in the communication industry, the engineering technicians who understand the theory and have the practical skills are trained [9].

\subsection{Innovate Student Management and Stimulate Students' Interest in Learning}

Establish an enterprise-oriented school atmosphere, upgrade the traditional management of students to career management, upgrade the traditional campus environment to enterprise environment, and upgrade the learning process of students to work process. Through the sand table simulation teaching and the three-section project-driven teaching based on the project management, the passive learning of the students is changed to the active practice, and the teacher's initiative teaching is the guidance of the invitation. Realize the innovation of student management mode and project-based teaching, which help students get competitive opportunities in the workplace [10].

ZTE college has invested nearly 50,000 yuan each year to carry out various student skills competition activities and student quality development training activities. The institute completely simulates the organizational structure of ICT enterprises and establishes an ICT virtual company which is completely dominated by students. The college's professional teachers and enterprise engineers advise the company and assist in resources and operations. KPI (Key Performance Indicator) management assessment system was introduced to strengthen the management of the company.

\subsection{Close Integration of Talent Training and Industry Certification}

We implement the "double certificate" construction system, which is college diploma and vocational qualification certificate. Encourage students to obtain vocational skills in order to improve their employment competitiveness. Integrate the enterprise's technical standards and skills training methods into professional teaching plans and courses. Now students can be passed the certificate of wireless technology engineers (including LTE, WCDMA, CDMA2000, GSM, and Network Planning and Optimization, etc), exchange technical engineers (including program-controlled exchange and NGN), transmission technology engineer (PTN), data communication engineer (routing exchange), access network engineer (xPON), etc.

\subsection{Improving the Quality of Employment and Entrepreneurship by Enterprise Employment Alliance}

The enterprise has a large number of industry agents and distribution agents. By play to the leading position of enterprises, we can help students find the ideal job. In recent years, on the premise of ensuring the $100 \%$ employment of students, we pay more attention to the professional counterparts and promotion rates.

Choose suitable opportunities for students to start their own businesses, and guide students to grasp the entrepreneurial ideas and basic skills. In order to support students to innovate and start their own businesses, we will implement the all-staff, whole-course and all-around tutorial system. The first-year students will be given quasi-occupational-oriented training, 
and second-year students will be trained in vocational orientation, development training and job search skills.

\section{Conclusion}

College-enterprise cooperation is an important measure to train high-quality skilled talents, and it is an important way to enhance the connotation of vocational colleges and highlight the characteristics of higher vocational education. ZTE, a communications equipment manufacturer, attaches great importance to college-enterprise cooperation and personnel training. It cooperates with Gansu Vocational and Technical College of Communications, including the construction of network college, the construction of practice training base, the development of teacher training, the construction of double certificates and social services. So it leads the construction and development of communication technology major.

In the practice of college-enterprise cooperation, we should further improve the relevant systems, innovate ideas and methods for cooperation, exploring the participation of the whole society, and promoting the sustainable development of deep cooperation. We will contribute to the development of high quality technical talents and to better serve the local economic construction.

\section{Fund Project}

Gansu provincial secondary vocational education provincial project in 2017 (NO. GS [2017] ZJ116)

\section{References}

[1] Exploration and Practice of College Enterprise Cooperation Mode Innovation in Higher Vocational Colleges under New Era and New Normal [J]. Wang G, Amp H R. Logistics Engineering \& Management, 2018.

[2] Curriculum Development Mechanism Research of
College-enterprise Cooperation in Higher Vocational Colleges [J]. Zhang N. Guide of Science \& Education, 2013.

[3] Research on the cooperation mechanism between higher vocational education and enterprise [A]. Luo Xiao Hui. Proceedings of 2016 4th International Conference on Management Science, Education Technology, Arts, Social Science and Economics (MSETASSE 2016) [C]. 2016.

[4] Exploration of ICT professional group construction in higher vocation colleges [J]. Luo Quanzhen, Zhang Yanzhou, Zhang Shihui. Experimental Technology and Management. Vol. 34, No. 3, 2017.

[5] Problems and countermeasures in-depth cooperation in higher vocational education schools and enterprises: Taking Gansu Vocational and Technical College of Communications of Information Engineering as an example. Zhang shihui, Yan wei, Tian hong. Experimental Technology and Management. 2012, 29 (11): 132-135.

[6] The Research and Practice on Colleges-Enterprise Cooperation for the Communication Engineering Speciality in Applied Colleges [J]. Mao-Sheng F U, Shi-Wei W U, Liu R J. Jornal of W Anh Nvry, 2013.

[7] Exploration of "Double Type" Teachers' Team-Building in Colleges Enterprise Cooperation to Co-constructing Practical Training Bases [A]. Wei CHEN. Proceedings of 2014 International Conference on Social, Education and Management Engineering (SEME 2014) [C]. 2014.

[8] Research on Training Mode of School Enterprise Cooperation in Higher Vocational Education [A]. Shuangyou Wang, Yang Jing. International Journal of Education and Management (DECEMBER 2016 V1 N4) [C]. 2016.

[9] Based on superior orders classes engineer curriculum reform practice of CDIO [J]. Zhang shihui, Qi yun, yan wei. Research in Higher Education of Engineering. 2014 (5): 187-190.

[10] Problems and Countermeasures of Student Management in Higher Vocational College under the Background of College-Enterprise Cooperation [A]. Lei Yang. Proceedings of 2015 2nd International Conference on Education and Education Research (EER 2015 V5) [C]. 2015. 